\title{
Note on sources
}

Translations into English are my own, unless otherwise indicated. Quotation of original texts in French has been limited when an original is available in a modern, online or facsimile source. Original quotations in French from restricted archival material have generally been included in notes. The spelling of quotations in French has been modernised but, to facilitate referencing, the titles of sources have been transcribed using the original spelling. The following abbreviations have been used for archival or unpublished material:

AdC Archives départementales du Cher, Bourges

AJPF Archives jésuites de la Province de France, Vanves

ANOM Archives nationales d'outre-mer, Aix-en-Provence

ARSI Archivum Romanum Societatis Iesu, Rome

ASPF Archivio Storico di Propaganda Fide, Rome

BM Bibliothèque Mazarine, Paris

$\mathrm{BnF} \quad$ Bibliothèque nationale de France, Paris

MdC Médiathèque de Carcassonne Agglo, Carcassonne 
Michael Harrigan - 9781526122254 Downloaded from manchesterhive.com at $04 / 26 / 2023$ 02:22:48PM 